\title{
THE USAGE OF TLS AND PHOTOGRAMMETRY DURING THE RESTORATION PROCESS OF SPANISH NATIONAL MONUMENT
}

\author{
Yolanda Spairani-Berrio ${ }^{1 *}$, Pascual Saura Gómez ${ }^{1}$, J. Antonio Huesca-Tortosa ${ }^{1}$, Silvia Spairani Berrio ${ }^{1}$, David Torregrosa Fuentes ${ }^{1}$ \\ ${ }^{1}$ Department of Architectural Constructions, Alicante University, Alicante, Spain. yolanda.spairani@ua.es; pascual.saura@ua.es; \\ jahuescat@gmail.com; silvia.spairani@ua.es; dtfuentes@hotmail.com
}

\author{
Commission II, WGII / 8
}

KEY WORDS: TLS, Photogrammetry, Cultural Heritage, Restoration methodology, Vaults restoration, Restoration survey.

\begin{abstract}
:
This article presents the multidisciplinary methodology employed in the restoration of a sixteenth century renaissance building with gothic vaults. The use of precise instrumental techniques like TLS (Terrestrial Laser Scanning) or photogrammetry are proposed to obtain the geometry of the building before, during and after the intervention. Obtaining the point clouds of the Refectory of the Santo Domingo de Orihuela School in their different restoration stages allows monitoring the vaults, studying their structural behaviour and deformations with the comparison of their original state, unloaded state and the new loading after the execution works.

A work methodology that is proposed in this article could be applied to any restoration work of patrimonial architecture.

The original deformations have been verified and quantified and the final state of the intervention has been documented with respect to the original state.
\end{abstract}

\section{INTRODUCTION}

In architectural restoration projects precise recording techniques are usually applied in the preliminary stage of data collection. TLS (Terrestrial Laser Scanning) and photogrammetry are techniques habituallly used because a high accuracy can be obtained when used properly (YASTIKLI, N., 2007) (MañanaBorrazás et al. 2008) (Vacca et al., 2012). Each building and monument requires an individualized treatment, so even though the methodology is general, its specific application for each case requires the adequacy to the problems to be solved. With respect to buildings with vault construction where it is impossible to access to their extrados, the initial registration remains partially incomplete. Data collection to document the geometry and construction systems of the building must be finished during the restoration works.

Santo Domingo de Orihuela School represents one of the most relevant architectural ensemble of the sixteenth century in the Comunidad Valenciana, not only because of its original plans, but also because of its execution quality. The builiding was designed by the architect Jerónimo Quijano in 1552 and three quarters of the original plans are preserved, but unfortunately the part where the Refectory is placed today is missing.

The place intended for the Refectory in the School has been changing through the years due to the need of a larger area because of the growing number of friars and students and this caused successive changes. The refectory is covered with a groin vault with transverse semicircular arches and the north gallery is finished with a splayed arch, with geometric caissons in obliquity. Needing only decoration and painting, the refectory was considered to be finished in 1595 . However, the year 1794 written on the refectory walls raises doubts about the actual date of execution of this part of the school. This fact justifies even more the need to document the restoration works, since elements of possible space modifications can be hidden under the current rendering.

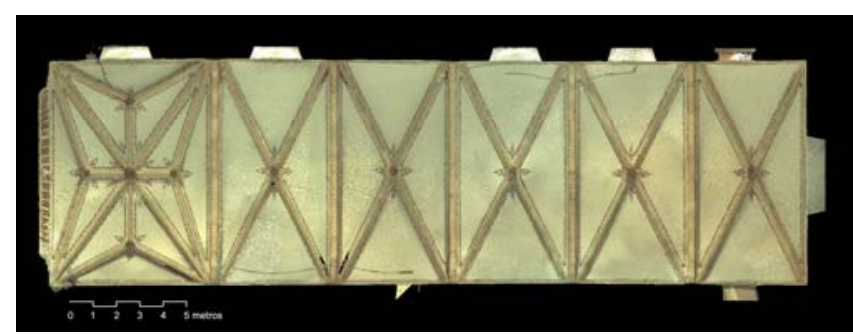

Figure 1: Zenith view of the vaults

There is a preservation master plan, where several stages of intervention were established giving priority to the parts of the ensemble which showed structural damages, was carried out in 2006. The Refectory was within these urgent stages of intervention since it showed structural damages with cracks in vaults and walls. The gabled roof on the upper rooms made of ridgepole framework structure was also very damaged and needed preservation.

\section{RELATED RESTORATION WORKS}

Restoration works main goal is the structural consolidation and restoration of the Refectory area due to the problems that it presents. The interventions are conducted under the supervision and support of a team of archaeologists and architects. The works, being executed now, are expected to be finished in July 
2019. The works already finished are briefly described and the ones that still remain to be done are commented.

2.1. Restoration works start protecting specific elements like tiling from the eighteenth century developed on the perimeter in all the base of the Refectory, and wall paintings at the header and the opposite end of the room.

2.2. Before the demolition works of the slabs, supported on the wall ribs, centering has been provided to ensure the safety and stability of the vaults and arches under slabs.

2.3. The outside wall has been stabilized and consolidated by injecting fluid lime mortar. The existing cracks in vaults and arches have been sealed with special lime mortars, and some stitching with fiberglass rods has been made. For the purpose of binding the walls closing the refectory, steel braces system has been prepared. The vaults extrados has been reinforced using rendering with two-component mortar fiberreinforced PLANITOP HDM, restoration reinforced with fiberglass mesh from the Mapei brand.

2.4. Subsequently, we have followed with the placing of the new horizontal half-timbered on the second floor (forged on the refectory) with unidirectional slabs using wooden laminated beams with waterproof double board beam filling and compression layer of $80 \mathrm{~mm}$ thickness lightweight concrete with electrowelded lath. Slabs with beams-joists of reinforced concrete carried out in situ are made in the outer area among buttresses. All of them bound on the perimeter by means of reinforced concrete and metal framing, in order to create a lattice on the perimeter binding all the slabs on the arches and walls limits.

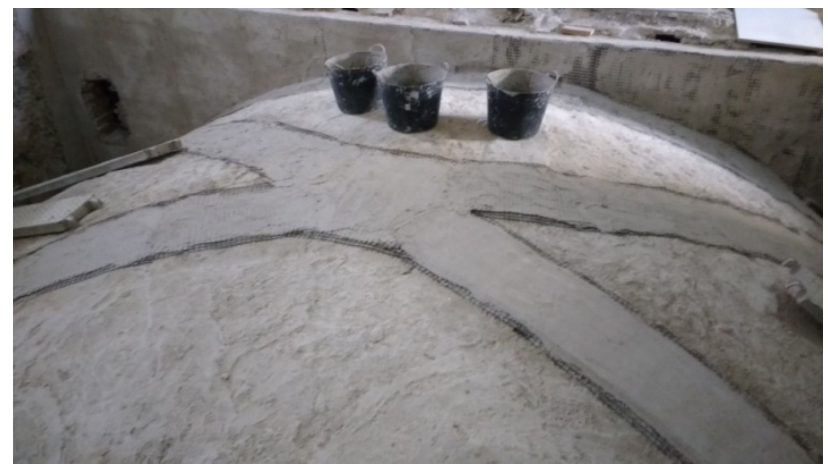

Figure 2: Reinforcement with Planitop HDM and fiberglass Mapei

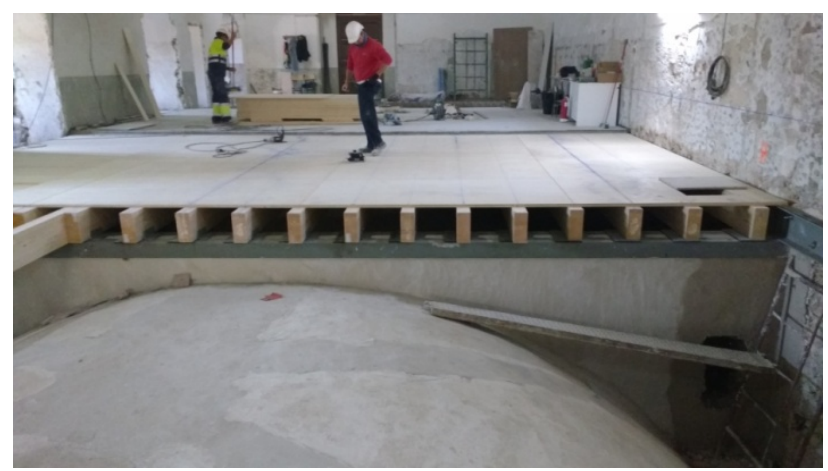

Figure 3: Reinforcement on wall ribs

\section{ABOUT STATE OF LOADS OF THE STRUCTURAL SYSTEM}

We are analyzed different points of the section type in the vaults and, at the same time, comparing the results between the different vaults and points observed in them, and the three phases that we have considered, which are different and comparable from the initial state of the works until their ending. To complete the study, an estimation of the load state of the structure is made in each of the phases analyzed. It has been considered the same state of charges for the arcs 1-2-3-4 and the arc 5 with different load bands (figure 5)

For this question, the specific weights of the elements that are in the construction system are taken into account:

Own weight of the vault, executed with two threads of solid brick taken with lime mortar and plasters of the extrados and intrados of the same mortar, with an average thickness of $12 \mathrm{~cm}$, and the consideration that the own weight of a brick factory solid with lime mortar is $1.8 \mathrm{~T} / \mathrm{m}^{3}$ that which is: $\mathrm{Q}_{\text {vault }}=0,12 \mathrm{~m} \mathrm{x}$ $1,8 \mathrm{~T} / \mathrm{m}^{3}=0,216 \mathrm{~T} / \mathrm{m}^{2}$

Own weight of the unidirectional floor that rests on the brick factories in arches, formed by wooden beams, simple vault with solid brick and hydraulic tile flooring on fillings and lime mortar. It has been considered an average thickness of $15 \mathrm{~cm}$ and one density of $1,6 \mathrm{~T} / \mathrm{m}^{3}$, and for wooden an average density of de $1 \mathrm{~T} / \mathrm{m}^{3}$; we could stimate a weight for the initial slab aproximately of $Q_{\text {initial slab }}=$ de $0,33 \mathrm{~T} / \mathrm{m}^{2}$

The line load of the 1 food brick factory (catalán format is 33 $\mathrm{cm}$ long) on the arches is de $\mathrm{Q}_{1}$ food factory $=0,54 \mathrm{~T} / \mathrm{m}^{2} \mathrm{x} \mathrm{h}$. This charge is changeble, minimun in the top $\mathrm{Q}_{\text {key arch }}=0,54 \mathrm{~T} / \mathrm{m}^{2} \mathrm{x}$ $0,25 \mathrm{~m}=0,135 \mathrm{~T} / \mathrm{m}$ and maximum in down $\mathrm{Q}_{\mathrm{start}}$ arch $=0,54 \mathrm{~T} / \mathrm{m}^{2}$ $\mathrm{x} 2,5 \mathrm{~m}=1,35 \mathrm{~T} / \mathrm{m}$, and in the 1 st of the light arch, it results $\mathrm{Q}_{1 / 4}$ light $=0,54 \mathrm{~T} / \mathrm{m}^{2} \times 0,75 \mathrm{~m}=0,4 \mathrm{~T} / \mathrm{m}$.

In addition, all nerves made of limestone with an approximate section of $0,20 \mathrm{~m} \times 0,40 \mathrm{~m}$ would be a line charge with uniform distribution of Q ribs-arcchs $=0,20 \mathrm{~m} \times 0,40 \mathrm{~m} \times 2,3 \mathrm{~T} / \mathrm{m}^{3}=0,84 \mathrm{~T} / \mathrm{m}$.

The following load state scheme is obtained corresponding to stage 1 (initial state).

\begin{tabular}{|c|c|c|c|c|c|c|c|c|}
\hline $\begin{array}{c}\text { First archs } \\
\text { state }\end{array}$ & Charges $\mathrm{T} / \mathrm{m}$ & First slab T/m & Vault $T / m$ & $\begin{array}{c}\text { Wall 1/light } \\
\mathrm{T} / \mathrm{m}\end{array}$ & $\begin{array}{c}\text { Wall 1/light } \\
\mathbf{T} / \mathbf{m}\end{array}$ & Arches $\mathrm{T} / \mathrm{m}$ & $\begin{array}{r}\text { First total } \\
\text { charge T/m }\end{array}$ & $\begin{array}{c}\text { Charge } \\
\text { without slab } \\
\text { T/m }\end{array}$ \\
\hline $1-2-3-34$ & Q L 1/4 & 1,65 & 1,08 & 0,4 & - & 0,84 & 3,97 & 2,32 \\
\hline $\begin{array}{l}(5 \mathrm{~m} \text { load } \\
\text { band) }\end{array}$ & Q L 1/2 & 1,65 & 1,08 & - & 0,13 & 0,84 & 3,89 & 2,05 \\
\hline 5 & Q L 1/4 & 2 & 1,3 & 0,4 & - & 0,84 & 4,54 & 2,54 \\
\hline $\begin{array}{l}\text { ( } \mathrm{cm} \text { load } \\
\text { bandd) }\end{array}$ & Q L 1/2 & 2 & 1,3 & - & 0,13 & 0,84 & 4,27 & 2,27 \\
\hline
\end{tabular}

Table 1. Loads of the structural system: first state

In the second phase considered, the initial slab has been demolished, and therefore the load state will be reduced by a surface load of $0.33 \mathrm{~T} / \mathrm{m}^{2}$, which corresponds to its weight and multiplied by the corresponding load band. For the present study, this state has not been considered for comparison through the proposed techniques of TLS, only for data collection and representation using photogrammetry techniques.

And in the third phase, the last state of the loads will be the weight of the new slab with executed pavement and the reinforcement based on a metal profile of 2 L 140 as a up ending of the 1 foot wall on the arches.

Regarding the new load of the slab made from new laminated wood beams, double waterproof plywood board, an $8 \mathrm{~cm}$ thick 
compression layer of lightened concrete with arlite, on which place a self-leveling mortar of medium thickness $5 \mathrm{~cm}$ and a wooden floor. All this means that the last slab assumes a surface load of $\mathrm{Q}=0,30 \mathrm{~T} / \mathrm{m}^{2}$

Also, the extrados of the vault have been reinforced with the same mortar and carbon fiber, and an average thickness, also of $2 \mathrm{~cm}$, which increases the surface load of the vault in $Q_{\text {vault }}$ reiforced $=1,6 \mathrm{~T} / \mathrm{m}^{3} \times 0,02 \mathrm{~m}=0,032 \mathrm{~T} / \mathrm{m}^{2}$

The following load state scheme is obtained corresponding to stage 3 (final state).

\begin{tabular}{|c|c|c|c|c|c|c|c|c|c|}
\hline $\begin{array}{l}\text { Last arches } \\
\text { state }\end{array}$ & Charges $\mathrm{T} / \mathrm{m}$ & Last slab T/m & Vault T/m & $\begin{array}{l}\text { Wall \% light } \\
T / m \text { h }\end{array}$ & $\begin{array}{l}\text { Wall 1/light } \\
\text { T/m }\end{array}$ & Arches $T / m$ & $\begin{array}{l}\text { Reinforcemen } \\
\text { tarch } T / m\end{array}$ & $\begin{array}{l}\text { Reinforceme } \\
\text { t vault T/m }\end{array}$ & $\begin{array}{l}\text { Last Charge } \\
T / m=\end{array}$ \\
\hline 1-2-3-3-4 & Q L 1/4 & 1,5 & 1,08 & & & 0.84 & 3.97 & 2.32 & 4,1 \\
\hline $\begin{array}{l}5 \text { (5 m load } \\
\text { band) }\end{array}$ & Q L 1/2 & 1,5 & 1,08 & & 0,13 & 0,84 & 3,89 & 2,05 & 3,89 \\
\hline 5 & Q L 1/4 & 1,8 & 1,3 & 0,4 & 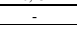 & 0,84 & 4,54 & 2,54 & 4,62 \\
\hline $\begin{array}{l}(6 \mathrm{~m} \text { load } \\
\text { band) }\end{array}$ & $\mathrm{Q} \mathrm{L}_{1 / 2}$ & 1,8 & 1,3 & - & 0,13 & 0,84 & 4,27 & 2,27 & 4,32 \\
\hline
\end{tabular}

Table 2. Loads of the structural system: last state

Therefore, the first and last load states are similar

\section{USAGE OF TLS AND PHOTOGRAMMETRIC TECHNIQUE IN THE MONITORING OF THE RESTORATION WORKS IN THE CULTURAL HERITAGE.}

The use of digital equipment has been chosen for the registration, study and monitoring of the refectory vaults. On the one hand, by means of the use of terrestrial LIDAR technology (Light Detection And Raging), by means of a highprecision laser scanner for data collection, its subsequent graphic records and three dimensions virtualization through softwares Cyclone, 3DReshaper (Leica softwares), VisualSFM (Changchang $\mathrm{Wu}, 2013$ ) (Changchang $\mathrm{Wu}, 2011$ ), Agisoft Metashape Professional and Cloudcompare (Cloudcompare, 2015), and the capture of high resolution images.

The laser scanner used consists of pulses (pulsed time-of-light), model ScanStation C10 Leica brand, and it measures through a laser beam generating a point cloud of the scanned element with a maximun density of one point every $2 \mathrm{~mm}$ distance, a complete field of vision of $360^{\circ}$ horizontal and $270^{\circ}$ vertical, with long range (up to $300 \mathrm{~m}$ ).

On the other hand, photogrammetry by VisualSfM is used, obtaining digital photography by taking photos using a reflex camera Canon EOS 600D, with an standard lens Canon EF-S $18-55 \mathrm{~mm}$. The photo processing has been made with Agisoft Metashape Professional software.

It has been considered the use of digital tools for documenting and monitoring the process of restoration of the refectory in 3 stages.

STAGE 1: Preliminary studies of the restoration project to elaborate a diagnostic study: The building is scanned with a laser scanner to record the project graphically, elaborate accurate planimetries and, from the point cloud generated, study structural deformations and behaviours that allow us to make hypothesis about the building situation and the pathologies origin.

The data collection was made before the intervention carried out using the point cloud provided by the technique used, reflecting the data in a graphic representation of different sections that allow us to analyze both the dimensions of the different construction systems as deformations and displacements produced, both the arches-nerves and the vaults. Of all the results obtained and in order to generate a valid criterion to analyze the behavior of the vaulted structure of the Refectory, has been considered in each of the nerves (archs 1,2, 3 and 4) points $\mathrm{A}, \mathrm{B}$ and $\mathrm{C}$ in the intrados of the arch, corresponding to $1 / 4,1 / 2$ and $3 / 4$ of the light, and that approximately concur with the kidneys and key of the archs.

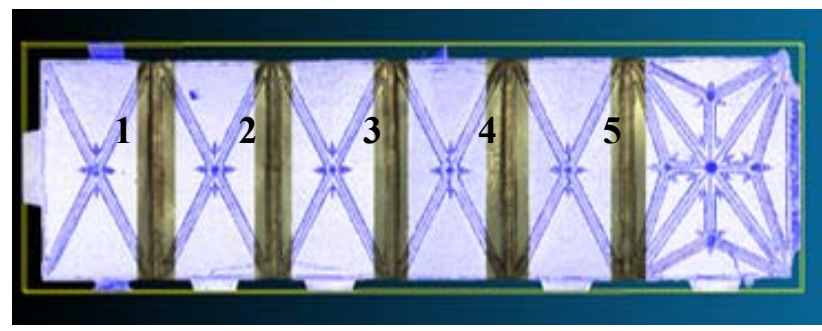

Figure 4: Part of vaulted structure: numbers of archs

STAGE 2: During the restoration works, the different stages of the project execution are scanned with laser scanner, demolition of partition walls and floors, vaults unloading... every construction and structural change or modification to observe, in comparison with the points cloud in stage 1, possible changes in vaults. This is the stage in which we get the vaults extrados record, being able to obtain their thickness and study of their construction system and structural behavior.

In this stage, photogrammetry (VisualSfM and Metashape) are used to document and record the different construction actions, walls and surfaces brought to light and also the structural reinforcements made in vaults and that remain hidden at the end of the restoration (Blanco, S. et al. 2015).

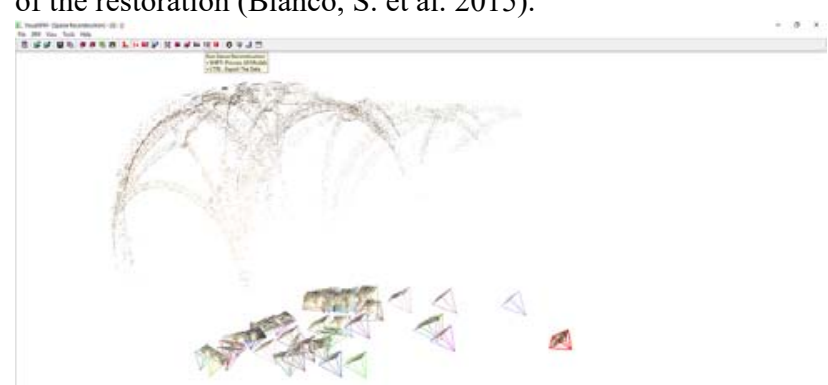

Figure 5: location of photographs in Visual SfM

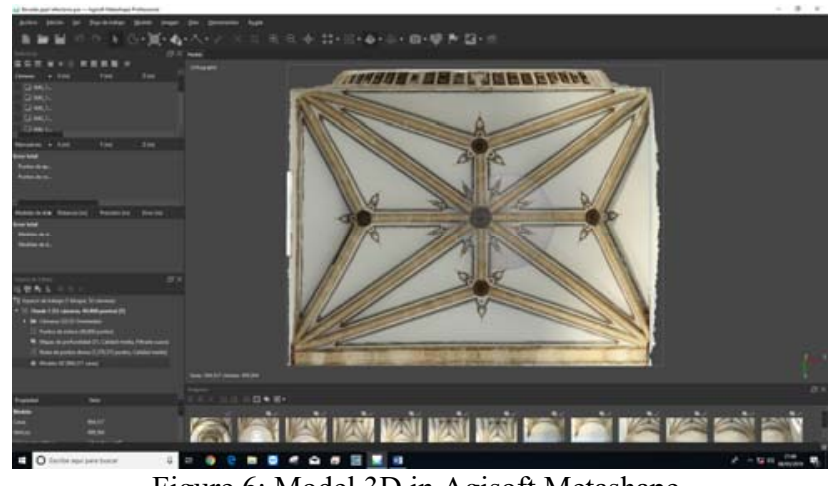

Figure 6: Model 3D in Agisoft Metashape 


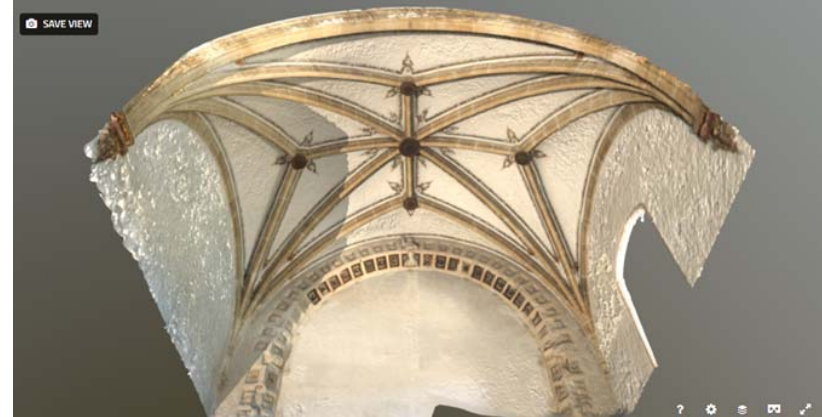

Figure 7: Model 3D with texture shared in Sketchfab

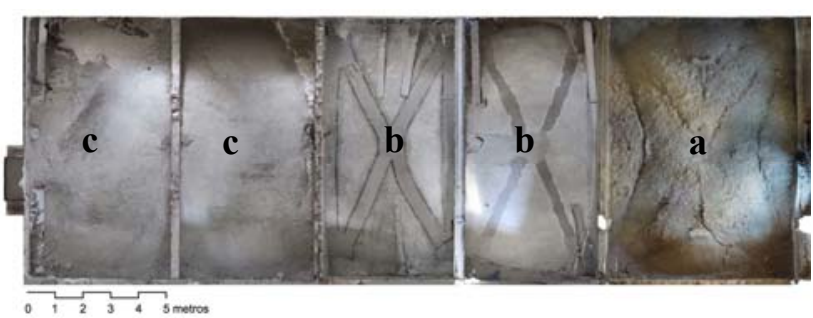

Figure 8: Vaults extrados on its different restoration stages (a): original, (b): during restoration, (c) finished. Photogammetric study by Agisoft Metashape

Actually these data have been registered but not considered in the research until now.

STAGE 3: The final state of the work after its restoration is scanned with a terrestrial laser scanner. Through this scanning we are allowed to compare the point clouds at the initial state, at Stage 1 and the final state at Stage 3, as well as the final geometry of the building. This part is still in progress.

This phase gets the slab again, in this case with a different system, but together with the loads that the reinforcements suppose by means of mortars and metal profiles, involves a state of loads very similar to the first one.

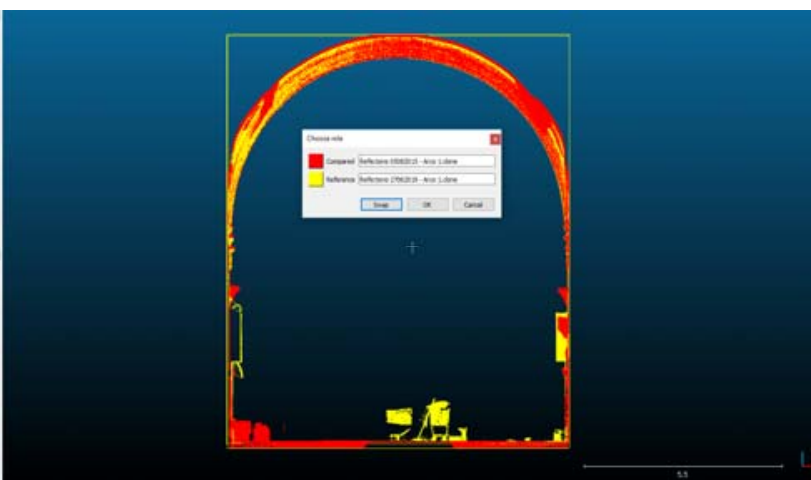

Figure 9: comparing cloud to cloud with Cloudcompare. Clouds data 2015 and 2019

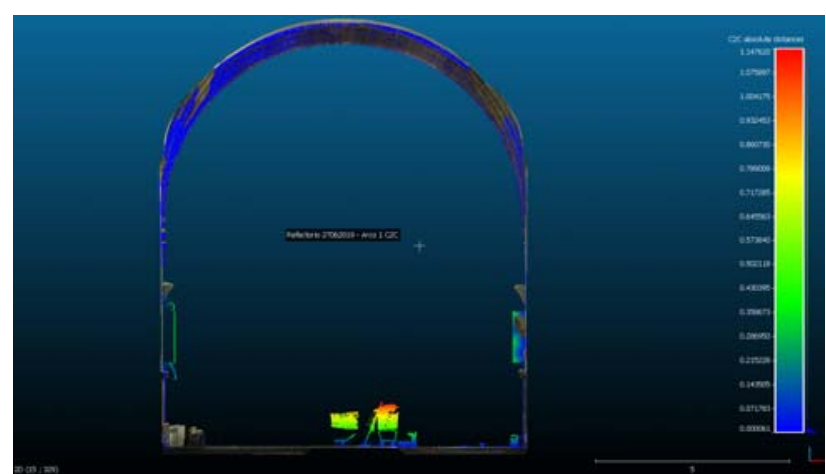

Figure 10: comparing cloud to cloud with Cloudcompare. Deformation study en arch 1

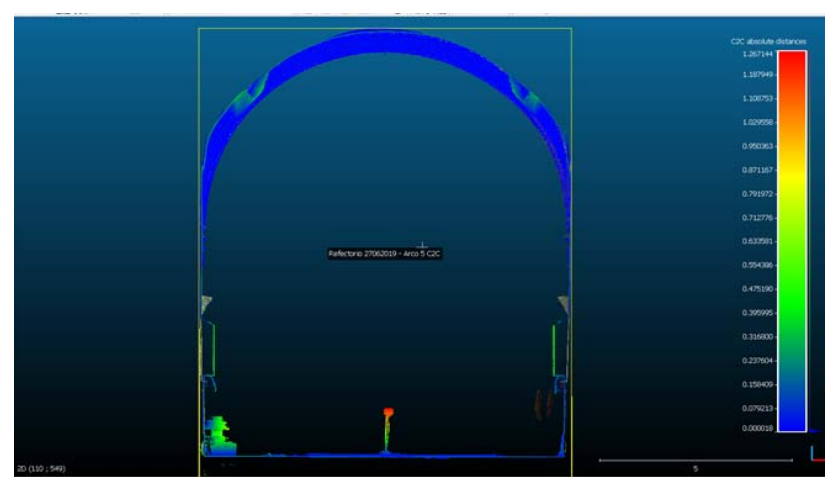

Figure 11: comparing cloud to cloud with Cloudcompare. Deformation study en arch 5

\section{RESULTS}

The usage of TLS and Photogrammetry in the monitoring of the Refectory Santo Domingo School has made possible the recording of its geometry accurately in addition to documenting graphically all the parameters and construction elements intervened during the works.

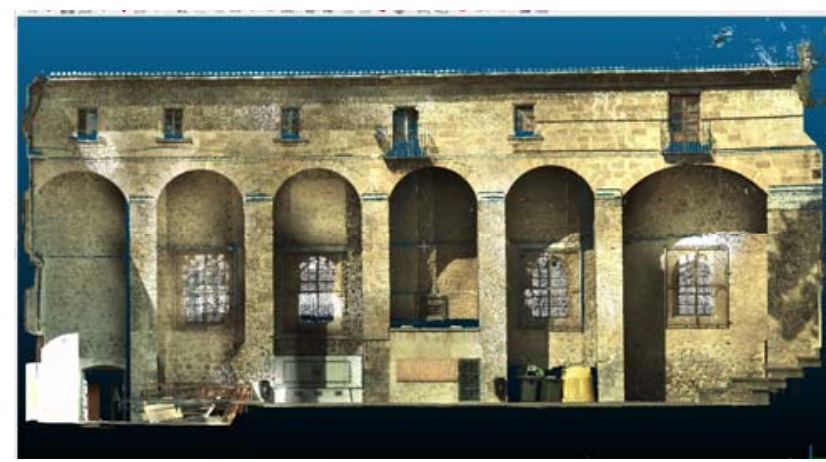

Figure 12: East facade with perceptible deformation

It is proposed, as working methodology in restorations similar to the one shown in this work, the usage of digital tools for documenting and monitoring the restoration process at the three working stages: in preliminary studies, in the execution of the works and in the restoration final state. (Cano, P. et al. 2010)

The works in progress in the refectory reinforce the building structure and at the same time reduce permanent loads by replacing the old heavy slabs with lighter ones. These modifications in the loads state, produce less stress in the buildings and vaults whose deformations are significantly reduced. This restoration aims at obtaining a firmer structural 
ensemble and better maintenance and durability conditions of the construction systems.

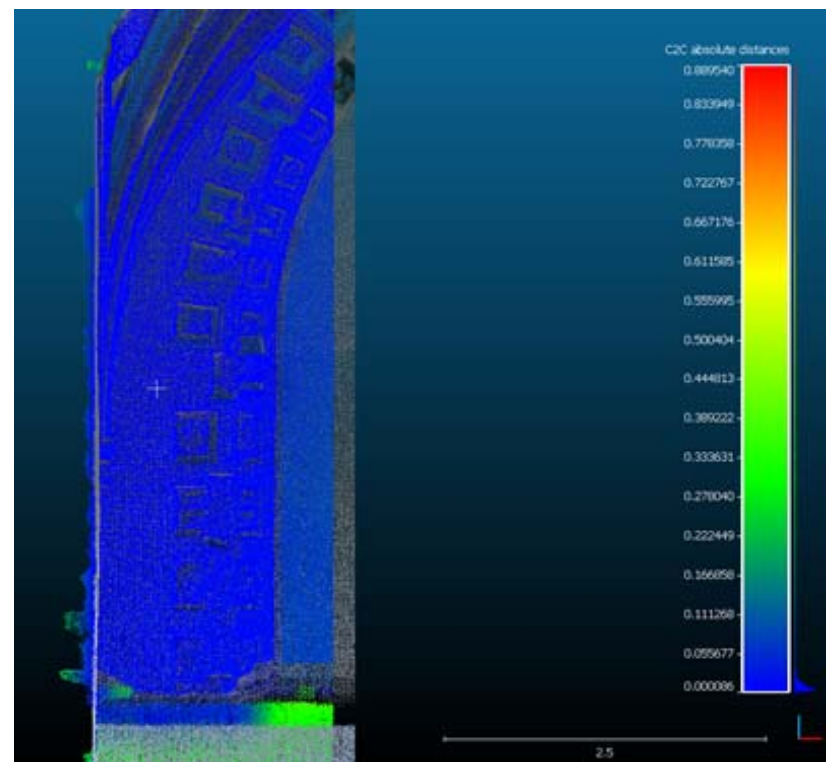

Figure 13: Crack location in wall: depth study and evaluation

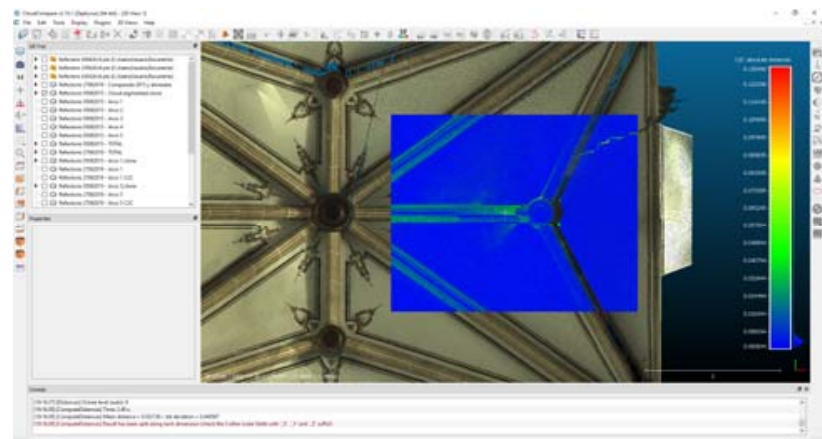

Figure 14: Deformation and descent of cross vault nerves moving evaluation

The point cloud achieved at the end of the works will be compared to the initial one to study possible recoveries in vaults deformations. It will also serve as a point cloud of reference for possible movements suffered by the building in the future.

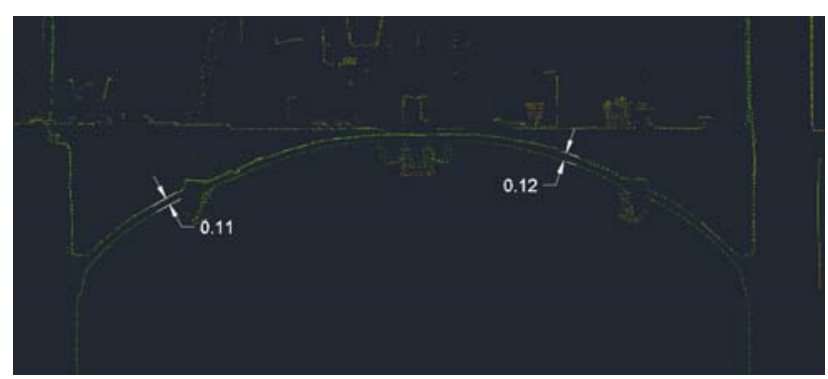

Figure 15: Point cloud section during the restoration works. The measure of the vault section can be obtained.
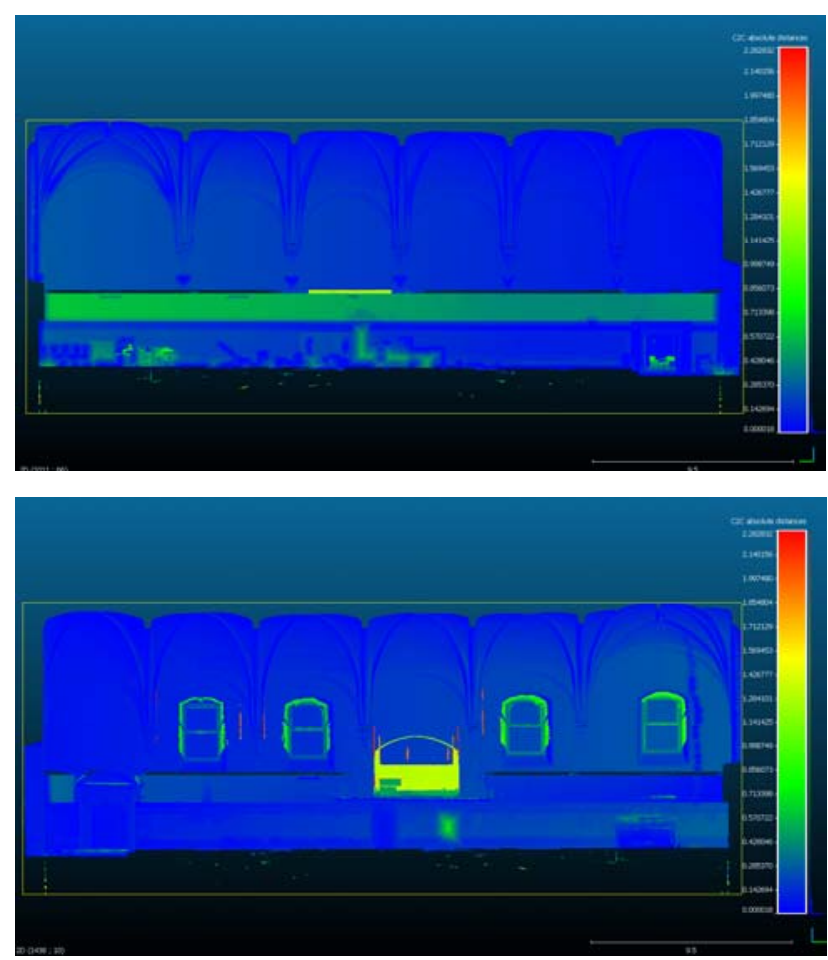

Figure 16: Cloud to cloud comparison (original state and final state) lateral east and west

\section{CONCLUSIONS}

The state of charges studied before and after the Rehabilitation interventions are substantially similar, so we can say that the structure of the Refectory receives permanent charges similar to those it had before these works.

The comparative studies carried out from the data collection with the techniques referred to in August 2015 and June 2019 (once the execution works of the new slabs have been completed, including the reinforcements in vaults and arches) reflect a null movement of the structures, no deformations have made compared with to the first state. The data obtained in the measurements reflect the point clouds and they contain absolute errors of the order in 1-3 mm, in such a way that the differences between the initial and final measurements are in the aforementioned interval of $1 \mathrm{~mm}$.

The reinforcing actions in the archs, cracks and back of the vaults have stabilized and secured the structural behavior of the Refectory.

With the comparison of point clouds (original-final) it has been possible to quantify the deformations of some elements, as well as their location. Specifically in relation to the areas affected by movements of the nerves of the vaults (difference of position in its initial state and its final final state, e.g. figure 13). And to quantify the depth of some of the most important cracks that the building presented (e.g. figure 12).

It has also been a great help to document the construction phases of the walls faithfully in order to carry out archaeological studies of them, currently in the drafting phase of the final archaeological and architectural report (e.g. figure 8 and 15)

Particularly interesting has been the particular study of some constructive elements that reflect the methodology used in the stonemasonry techniques by the master stonemasons of the time 
(it has been possible to document photogrammetrically the traces on the stones themselves). On this subject, we are currently working and with which we intend to carry out a detailed study for your next scientific dissemination.

\section{ACKNOWLEDGEMENTS}

Thanks to the Rev. D. Jose Maria Fernandez-Corredor Soriano director of the Santo Domingo diocesan college, to the Diocese of Orihuela-Alicante for supporting the development of this study, to the University of Alicante for the technical means provided for the monitoring and registration of the data obtained through the scan and to the company Lorquimur for the facilities in the collection of data during the monitoring of the works in the intervention in the refectory.

\section{REFERENCES}

Agisoft Metashape Professional, 2019, Agisoft Metashape Professional version 1.5.1. Agisoft, http://www.agisoft.com [software]

Blanco, S., Carrión, B., \& Lerma, J. L. (2015). Documentación patrimonial mediante soluciones fotogramétricas y de escaneado láser, y su orientación a la generación de entornos virtuales. In La Ciencia y el Arte V. Ciencias experimentales y conservación del patrimonio (pp. 56-69). Subdirección General de Documentación y Publicaciones.

Changchang Wu, 2013, Towards Linear-time Incremental Structure From Motion, 3DV

Cano, P., Álvarez, F. L., Torres, J. C., \& del Mar Villafranca, M. (2010). Uso de escáner láser 3D para el registro del estado previo a la intervención de la Fuente de los Leones de La Alhambra. Virtual Archaeology Review, 1(2), 89-94.

Changchang Wu, 2011, VisualSFM: A Visual Structure from Motion System. http://ccwu.me/vsfm/

CloudCompare, 2019, CloudCompare Ver. 2.10.1 (Zephyrus): Paris, EDF R\&D, Telecom ParisTech. http://www.cloudcompare.org/ Licence: GNU GPL (General Public Licence) [Software].

Mañana-Borrazás, P., Rodríguez Paz, A., \& Blanco-Rotea, R. (2008). Una experiencia en la aplicación del Láser Escáner 3D a los procesos de documentación y análisis del Patrimonio Construido: su aplicación a Santa Eulalia de Bóveda (Lugo) y San Fiz de Solovio (Santiago de Compostela). Arqueología de la Arquitectura, 0(5), 15-32. doi: http://dx.doi.org/10.3989/arq.arqt.2008.87

YASTIKLI, N., 2007, Documentation of cultural heritage using digital photogrammetry and laser scanning, Journal of Cultural Heritage, $\mathrm{n}^{\mathrm{o}} 8$ (4), $\quad$ pp. 423 -427. doi: https://doi.org/10.1016/j.culher.2007.06.003

Vacca, G., Deidda, M., Dessi, A., \& Marras, M. 2012. Laser scanner survey to cultural heritage conservation and restoration. International Archives of the Photogrammetry, Remote Sensing and Spatial Information Sciences, Volume XXXIX-B5, 2012. XXII ISPRS Congress, 25 August - 01 September 2012, Melbourne, Australia 